\title{
Compliance with Universal Precautions Among Nurses and Laboratory Technicians in Mansoura International Specialized Hospital
}

\author{
Sahar Mamoud Sayed Ahmed; Salwa Abbas Aly Hassan \\ and Eman Shokry Abd Allah
}

\author{
Department of Community Health Nursing \\ Faculty of Nursing, Zagazig University
}

\begin{abstract}
Compliance with universal precautions by nurses and laboratory technicians in hospitals is very important because it prevent cross infection and decrease costs of antibiotics and antipyretics. Also, it decreases spread of infection, which leads to decrease morbidity and mortality rate. A cross-sectional descriptive design was used for conducting this study. The sample of the study consisted of 150 nurses and lab technicians working at morning shift in a hospital at Mansoura City, Dakahlia Governorate. Data were collected using a questionnaire sheet and an observation checklist. The study revealed that majority $(86.66 \%)$ of the studied sample of nurses and lab technicians aged less than 30 years. Also, majority of the studied sample have poor knowledge about sign and symptom and transmission of AIDS. In addition, about $94 \%$ of the studied samples have poor knowledge about signs, symptoms and mode of transmissions of hepatitis B and C virus infection. All of the studied sample reported that there are no eye protections in the hospital. Positive correlations between nurses' and lab technicians' practice and available supplies in the hospital were found, but the relations were not statistically significant. The exception was the item of the infection prevention ways which has a significant statistical relation. Also, positive correlations between lab technicians' and nurses' practice and their attending for training courses about infection control were found, but the relations were not statistically significant.
\end{abstract}

\section{Introduction}

The term infection was defined as a condition state that results from the presence of a pathogen in/on the body. A pathogen is a disease producing microorganism (Taylor et al., 2001).

Nosocomial infection refers to the clinically active infection occurring in a hospitalized patient that was not present or incubating at the time of admission. Nosocomial infections are common causes of illness and death among hospitalized patients. Surveillance of nosocomial infection is regarded as an essential part of the infection control program (Dewit, 2001 and Castledine \& Close, 2007).

The risk factors contributing to the development of nosocomial infections can be grouped into three categorgories: environment, therapeutic regimen, and the resistance of the patient (Parsons and Krau, 2007). Moreover, nosocomial infections in developing countries is not well recorded because insufficient funding for surveys and publication of such data (Faria et al., 2007). In Egypt, estimating the burden of disease associated with hospital -acquired infection is challenging because of limited surveillance activities and limited microbiology capacities in some public sector facilities. In addition, the complexity of applying the routine system of reporting infection and complexity of case definitions hinders the availability of such data (Talaat et al., 2006).

Data estimate that among the 35 million health care workers world wide, approximately 3 million experience percutaneous exposures to blood borne viruses each year (2 million HBV; 900,000 HCV and 300,000 HIV). These injuries are estimated to result in 66,000 hepatitis BV; 16,000 hepatitis CV and 2000 to $5000 \mathrm{HIV}$ infection (WHO, 2004). More than $90 \%$ of these infections are occurring in lowincome countries, and most are preventable (Karmode et al., 2005). 
Universal precautions (UPs) can be defined as recommended work practices to protect health care workers (HCWs) from exposure to blood born pathogens, and prevent nosocomial transmission (Karmode et al., 2005). The implementation of UPs helped to prevent direct contact with blood, and body fluids. Accordingly, it significantly decreased the number of exposure incidents by using protective barriers (including gloves, face mask, protective eyewear, overhead cap, gowns), hand washing after gloves disposal, unrecapping needles, hygienic disposal of medical wastes, and sterilization of surgical instruments (Rosdable, 2000).

Studies revealed that nurses and laboratory technicians reported significantly more percutaneous and mucocutaneous incidents than other health professionals. It was also found that the majority of blood exposure incidents occurred in operating theaters, and lab rooms (Knight \& Bods, 1998 and Duerink et al., 2006). Nurses at world level can minimize risks of nosocomial infection, and reassure patients in relation to these risks. An understanding of the importance of practices of universal precautions can minimize the harm of hospital infection (Storr et al., 2005).

The aim of the study

This study was designed to assess knowledge and practice of nurses and lab technicians about measures of compliance with universal precautions in Mansoura International Specialized Hospital (MISH).

\section{Material and Methods}

\section{Research design:}

A descriptive, cross-sectional design was used for conducting this study.

\section{Setting:}

The study was carried out at Mansoura International Specialized Hospital, Dakahlia Governorate.

\section{Subjects:}

The study was carried out on all nurses (110 nurses) and lab technicians (40 lab technicians) working in MISH at morning shift and accepted to participate in the study.

\section{Tools for data collection:}

Two tools were used for data collection:

\section{A- Questionnaire sheet}

A questionnaire was prepared to collect data about:

* Personal characteristics of the studied subjects, which include age, sex, marital status, education level, previous work experience, and in service training courses about methods of infection control.

* Knowledge of the studied subjects about causative agents of some types of blood born diseases, mode of transmission from patient to another patient, signs and symptoms of these diseases, and their complications.

* Knowledge of the nurses and lab technicians about disinfectant and sterilization, hand washing, management of wastes and sharp wastes...etc.

* Knowledge about presence of supplies and equipments needed to apply universal precautions in the hospital such as availability of basins for hand wash, soap or disinfectant solution, betadine pump, alcohol, towels or paper towels, needle box, autoclave, enough surgical instruments, over head, surgical or sterile gloves, aprons, mask, gowns, disposable gloves, over shoes, and eye protective glasses.

\section{Assessment of the knowledge:}

A scoring system for the questionnaire sheet consisted of given "0" score for wrong answer, "1" score for the incomplete correct answer and "2" score for the complete correct answer. The total score was calculated for each studied subject by adding scores of all items of the questionnaire. The total score was 98 grades $(100 \%)$. The studied subject considered had adequate knowledge when the total score equal or above $60 \%$, and inadequate if below $60 \%$.

\section{B- The observation checklist}

An observation checklist was developed after review the literature. It was required to monitor the compliance of nurses and lab technicians with universal precautions in the hospital and consisted of four parts: 
The first part; included nine items related to hand wash procedures, such as washing with fresh water and soap or disinfectant solution, indications of hand washing such as between patients, before each procedure, after handling contaminated equipments, and contact with blood or patient secretions.

The second part; contains five items about personal protective measures such as wear mask when dealing with patient with upper respiratory infection, wound dressing, also wearing gowns, aprons and gloves.

The third part; composed of four items cover personal hygiene such as remove jewelry, clean and tidy uniform which change daily or if became unclean for any reason, and also, clean cut hand nails. sections:

The fourth part; composed of two

- The first section included 10 items related

to environmental care such as presence of disinfectant solution, box for used needle, and covered container for used waste.

- The second section composed of 8 items related to patient's care, such as proper place for preparing medications, clean ward with disinfectant solution ... etc.

\section{Scoring of the practice:}

The scoring system for the observation sheet consists of given "1" score for the step done correctly and " 0 " for not done step. The total score for the observation sheet was 36 grades. The nurse had satisfactory performance when the total score equal or above $60 \%$, and unsatisfactory if below $60 \%$.

\section{Administrative design:}

An official permission was obtained from medical and nursing director of Mansoura International Specialized Hospital to perform this work.

\section{Pilot study:}

Before starting the practical phase a pilot study was done on 10 nurses and 5 lab technicians to test the questionnaire and observation checklist as regard clarity and coding process and to assess the respondent's acceptance and understanding the questions. The questionnaire and observation checklist were accordingly modified.

\section{The data collection phase:}

All the study subjects were given questionnaire sheets and instructed how to fill it by the researcher who met them personally. The researcher met ten nurses and five lab technicians every day in the hospital. The time needed for fill the questionnaire was $20-25$ minutes.

The observation checklist was filled by the researcher according to the observed nurses' and lab technicians' practice of infection control precautions in the hospital. Intermittent observation approach was used in from of a 3 hours in the morning shift at different days of the week. Each nurse was observed 3 times during data collection period. The duration of data collection was 6 months started from March to August 2007.

\section{Statistical analysis:}

The collected data were entered computer and suitable statistical formulas were used. The data were presented in a descriptive forms, tables and figures. The mean and standard deviation of each area of performance were computed, data were transferred to the SPSS version 9.0. Also, correlation was used; the significance level was accepted if the P-value $\leq 0.5$.

\section{Results}

Table (1): Shows distribution of the studied subjects according to their personal characteristics. The table showed that the mean age of the studied subjects were 25.66 \pm 2.1 years, seventy percent were females and more than half $(53.33 \%)$ were married. Concerning the qualification, less than half (46.33\%) of the sample had a nursing school diploma while the remaining $26.66 \%$ of the sample had bachelor in nursing and $24 \%$ of the sample had diploma in laboratory. Sixty percent of them had experience less than five years, and $60 \%$ attended training course about infection control.

Table (2): Shows the knowledge of the studied sample about AIDS. The table indicated that the majority of the studied 
sample $(86.66 \%)$ mentioned virus was the causative gent of AIDS, and only, 20\% reported complete correct answer about sings and symptoms of AIDS. On the other hand, $28.66 \%$ mentioned complete correct answer about ways of transmission of AIDS from infected patient to another person.

Table (3): Illustrated the studied subject's knowledge about viral hepatitis B. According to the results; $88.66 \%$ of them mentioned the causative agent of hepatitis $\mathrm{B}$ was virus, and the majority $(92.66 \%)$ reported complete correct answer about its complications. Moreover, only few of the studied subjects reported complete correct answer about sign and symptoms, and mode of transmission $(2.67 \%$ and $4 \%$, respectively).

Table (4): Shows the knowledge of the studied subjects about hepatitis C. Most of the studied sample (97.34\%) know causative agent of hepatitis C. Also, 96.67\% reported complete correct answer about its complications. On the other hand, $6 \%$ reported complete correct answer about its sings and symptoms, and $6.66 \%$ reported complete correct answer about mode of transmission of hepatitis $\mathrm{C}$ from infected patient to another person.

Figure (1): Illustrated that only $46.66 \%$ reported complete correct answer about types of nosocomial infection.

Table (5): Presented the knowledge of studied subjects about availability of equipments and supplies for universal precautions in the hospital. According to the nurses' answers most of equipments and supplies needed for universal precautions were present but inadequate. The majority of the subjects $(80 \%)$ reported present of autoclave, while $60 \%$ mentioned present of special container for disposing sharp equipments. Also, more than half reported presence adequate hand washing basin, and betidine detergent. On other hand, half or more of the studied sample mentioned alcohol, masks, sterile gloves, gown, and hard gloves were present but not enough amount. All subjects mentioned the eye protections not available in the hospital.

Table (6): The table shows the correlation between nurses' and lab technicians' practice and available supplies in the hospital. The correlations were positive, but not statistically significant except the item of the ways of infection prevention had a significant statistical correlation $(\mathrm{P}<0.05)$.

Table (7): The table shows the correlation between lab technicians' and nurses' practices and their attending training courses about infection control. The correlations were positive, but statistically insignificant $(\mathrm{P}>0.05)$.

Table (8): The table shows that there is a positive correlation between lab technicians' and nurses' total knowledge and their total practices. Statistically significant correlation could be shown between lab technicians' and nurses' total knowledge and their total practices $(\mathrm{P}<0.05)$.

Figure (2): Illustrated the levels of knowledge and practice among the studied subjects about universal precautions. According to the figure, only $60 \%$ of the subjects had adequate level of knowledge about infection control measures, while $53.67 \%$ of them had adequate practice. 
Table (1): Distribution of the studied subjects according to their personal characteristics.

\begin{tabular}{|c|c|c|}
\hline Demographic characteristics & Frequency & Percent \\
\hline $\begin{array}{l}\text { Age (years): } \\
<25 \\
25- \\
30- \\
35>\end{array}$ & $\begin{array}{l}90 \\
40 \\
15 \\
5\end{array}$ & $\begin{array}{c}60.00 \\
26.67 \\
10.00 \\
3.33\end{array}$ \\
\hline $\mathrm{X} \pm \mathrm{SD}$ & \multicolumn{2}{|c|}{$25.66 \pm 2.1$} \\
\hline $\begin{array}{l}\text { Sex: } \\
\text { Female } \\
\text { Males }\end{array}$ & $\begin{array}{c}105 \\
45\end{array}$ & $\begin{array}{l}70 \\
30\end{array}$ \\
\hline $\begin{array}{l}\text { Marital status: } \\
\text { Single } \\
\text { Married } \\
\text { Divorced } \\
\text { Widowed }\end{array}$ & $\begin{array}{c}62 \\
80 \\
6 \\
2\end{array}$ & $\begin{array}{c}41.33 \\
53.33 \\
4 \\
1.33\end{array}$ \\
\hline $\begin{array}{l}\text { Level of education: } \\
\text { Diploma in nursing } \\
\text { Bachelor of science } \\
\text { Bachelor of nursing } \\
\text { Diploma of laboratory }\end{array}$ & $\begin{array}{c}70 \\
4 \\
40 \\
36\end{array}$ & $\begin{array}{c}46.66 \\
2.66 \\
26.66 \\
24\end{array}$ \\
\hline $\begin{array}{l}\text { Job title: } \\
\text { Nurses } \\
\text { Nursing supervisors } \\
\text { Head nurses department } \\
\text { Lab technicians }\end{array}$ & $\begin{array}{l}70 \\
20 \\
20 \\
40\end{array}$ & $\begin{array}{l}46.66 \\
13.33 \\
13.33 \\
26.66\end{array}$ \\
\hline $\begin{array}{l}\text { Years of experience: } \\
<5 \\
5- \\
10+\end{array}$ & $\begin{array}{l}90 \\
35 \\
25\end{array}$ & $\begin{array}{c}60 \\
23.34 \\
16.66\end{array}$ \\
\hline $\mathrm{X} \pm \mathrm{SD}$ & \multicolumn{2}{|c|}{$6.8 \pm 0.53$} \\
\hline $\begin{array}{l}\text { Attending training courses about infection control: } \\
\text { No } \\
\text { Yes }\end{array}$ & $\begin{array}{l}60 \\
90\end{array}$ & $\begin{array}{l}40 \\
60\end{array}$ \\
\hline
\end{tabular}

Table (2): Knowledge of the studied subjects about AIDS.

\begin{tabular}{|l|c|c|}
\hline \multicolumn{1}{|c|}{ Knowledge about AIDS } & Number & Percent \\
\hline Causative agent: & 130 & 86.66 \\
Virus & 5 & 3.33 \\
Bacteria & 15 & 10 \\
Don't know & & \\
\hline Singe and Symptom: & 30 & 20 \\
Complete correct answer & 70 & 46.66 \\
Incomplete correct answer & 50 & 33.33 \\
Wrong answer & & \\
Transmission of AIDS from infected patient to another person: & 43 & 28.66 \\
Complete correct answer & 80 & 53.33 \\
Incomplete correct answer & 27 & 18 \\
Wrong answer & & \\
\hline
\end{tabular}


Table (3): Knowledge of the studied sample about viral hepatitis B.

\begin{tabular}{|l|c|c|}
\hline \multicolumn{1}{|c|}{ Knowledge about hepatitis B } & Number & Percent \\
\hline Causative agent: & 133 & 88.66 \\
Virus & 10 & 6.66 \\
Bacteria & 7 & 4.66 \\
Don't know & 4 & \\
\hline Singe and Symptom: & 144 & 2.67 \\
Complete correct answer & 2 & 96 \\
Incomplete correct answer & & \\
Wrong answer & & \\
\hline Mode of transmission of hepatitis B from infected patient to & 6 & 4 \\
another person: & 142 & 94.67 \\
Complete correct answer & 2 & 1.33 \\
Incomplete correct answer & & \\
Wrong answer & 139 & 92.66 \\
\hline Complications: & 10 & 6.66 \\
Complete correct answer & 1 & 0.66 \\
Incomplete correct answer & & \\
Wrong answer & & \\
\hline
\end{tabular}

Tab (4): Knowledge of the studied subjects about viral hepatitis $C$.

\begin{tabular}{|l|c|c|}
\hline \multicolumn{1}{|c|}{ Knowledge about hepatitis C } & Number & Percent \\
\hline Causative agent: & 146 & 97.34 \\
Virus & 4 & 2.66 \\
Bacteria & 0 & 0.0 \\
Don't know & & \\
\hline Singe and Symptom: & 9 & 6.0 \\
Complete correct answer & 138 & 92 \\
Incomplete correct answer & 3 & 2 \\
Wrong answer & & \\
\hline Mode of transmission of hepatitis C from infected patient to & 10 & 6.66 \\
anther person: & 139 & 92.66 \\
Complete correct answer & 1 & 0.66 \\
Incomplete correct answer & & \\
Wrong answer & 145 & 96.67 \\
\hline Complications: & 5 & 3.33 \\
Complete correct answer & 0 & 0.0 \\
Incomplete correct answer & & \\
Wrong answer & & \\
\hline
\end{tabular}




\section{Figure (1): The studied subjects's knowlege about types of nosocomial infections.}

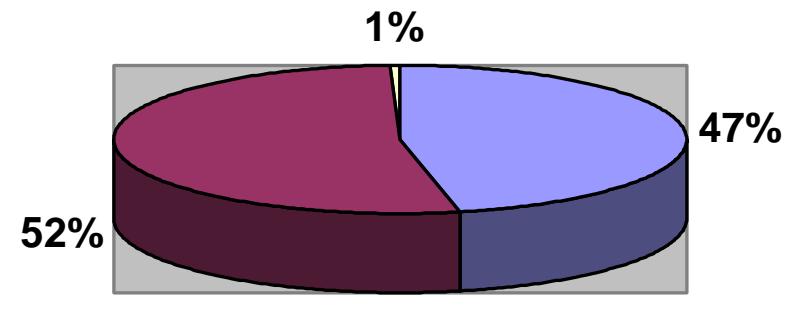

\begin{tabular}{|l|}
\hline complete correct \\
answer $46.66 \%$ \\
$\square$ incomplete correct \\
answe \\
$\square$ wrong answer
\end{tabular}

Table (5): knowledge of the studied subjects about availability of equipments and supplies for universal precautions in the hospital.

\begin{tabular}{|l|c|c|c|c|c|c|}
\hline \multirow{2}{*}{\multicolumn{1}{|c|}{ Equipment }} & \multicolumn{2}{c|}{$\begin{array}{c}\text { Yes } \\
\text { and enough }\end{array}$} & \multicolumn{2}{c|}{$\begin{array}{c}\text { Yes } \\
\text { and not enough }\end{array}$} & \multicolumn{2}{c|}{ No } \\
\cline { 2 - 7 } & No. & \% & No. & \% & No. & \% \\
\hline - Hand washing basin & 80 & 53.33 & 50 & 33.34 & 20 & 13.33 \\
- Soap for hand washing & 70 & 46.67 & 70 & 46.67 & 10 & 6.66 \\
- Towels or paper for drying hands & 66 & 44 & 82 & 54.66 & 2 & 1.34 \\
\hline - Alcohol & 40 & 26.67 & 85 & 56.67 & 25 & 16.66 \\
- Betidine detergent & 85 & 56.66 & 65 & 43.34 & 0 & 0.0 \\
- Availability disinfectant solution & 60 & 40 & 80 & 52.34 & 10 & 6.66 \\
- Disinfectant containers & 65 & 43.34 & 70 & 46.66 & 15 & 10 \\
\hline - Mask & 58 & 38.67 & 82 & 54.67 & 10 & 6.66 \\
- Apron & 40 & 26.67 & 70 & 46.67 & 40 & 26.66 \\
- Gown & 37 & 24.66 & 78 & 52 & 35 & 23.33 \\
- Disposal gloves & 60 & 40 & 80 & 53.34 & 10 & 6.66 \\
- Sterile gloves & 36 & 24 & 90 & 60 & 24 & 16 \\
- Hard work gloves & 20 & 13.34 & 100 & 66.66 & 30 & 20 \\
- Eye protections & 0 & 0.0 & 0 & 0.0 & 15 & 100 \\
- Overhead & 63 & 42 & 81 & 54 & 6 & 4 \\
- Overshoes & 25 & 16.66 & 110 & 73.34 & 15 & 10 \\
\hline - Autoclave & 120 & 80 & 30 & $20 \%$ & 0 & 0.0 \\
- Surgical instruments & 50 & 33.33 & 100 & 66.67 & 0 & 0.0 \\
- Drugs car & 65 & 43.34 & 80 & 53.33 & 5 & 3.33 \\
- Dressing car & 60 & 40 & 83 & 55.34 & 7 & 4.66 \\
- Special container for sharps disposal & 90 & 60 & 57 & 38 & 3 & 2 \\
\hline - Policy for deep insertion & 79 & 52.67 & 70 & 46.67 & 1 & 0.66 \\
\hline
\end{tabular}




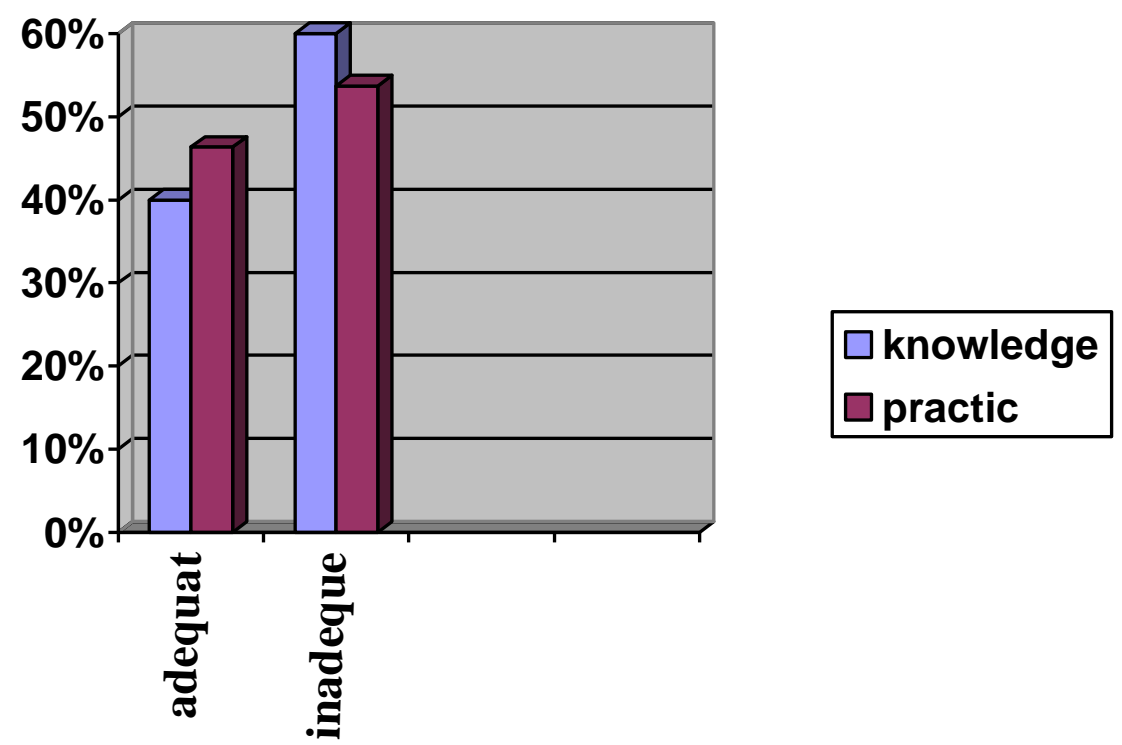

Figure (2): Level of knowlege and practice among the stuied sample.

Table (6): Correlation between nurses' and lab technicians' practice and available supplies in hospital.

\begin{tabular}{|l|c|c|}
\hline \multicolumn{1}{|c|}{ Practice } & Correlation ( r ) & P-value \\
\hline - Hand washing & 0.17 & $>0.05$ \\
- Personal protective equipment & 0.2 & $>0.05$ \\
- Personal hygiene & 0.16 & $>0.05$ \\
- Ways of infection prevention & 0.48 & $<0.05$ \\
\hline
\end{tabular}

Table (7): Correlation between nurses' and lab technicians' practice and their attending training courses about infection control.

\begin{tabular}{|l|c|c|}
\hline \multicolumn{1}{|c|}{ Practice } & Correlation ( r ) & P-value \\
\hline - Hand washing & 0.18 & $>0.05$ \\
- Personal protective equipment & 0.15 & $>0.05$ \\
- Personal hygiene & 0.17 & $>0.05$ \\
- Ways of infection prevention & 0.14 & $>0.05$ \\
\hline
\end{tabular}

Table (8): Correlation between total subjects' knowledge and practice.

\begin{tabular}{|c|c|c|}
\hline \multirow{2}{*}{ Item } & \multicolumn{2}{|c|}{ Practice score } \\
\cline { 2 - 3 } & Pearson correlation coefficient & P-value \\
\hline Knowledge score & 0.89 & $<0.05$ \\
\hline
\end{tabular}




\section{Discussion}

The present study attempted to assess nurses' and lab technicians' knowledge as well as monitor compliance of the nurses and lab technician's with universal precautions. The study sample consisted of 110 nurses and 40 lab technicians in Mansoura International Specialized Hospital. Most of the subjects were females and nearly one third of them were males. Regarding their ages, most of the subjects were in the age group <25 years. As regard their experience, $83.33 \%$ of them had experience less than 10 years and $16.66 \%$ had experience more than 10 years. Also, about two thirds of them attended training courses about infection control. The finding of the present study agrees with El Toukhy (1996), who commented that the hospital is responsible for performing in service education particularly related to those who have higher incidence of nosocomial infections. Furthermore, education program should be widely employed for infection control in the intensive care unit setting and can lead to substantial decreases in cost, and patient mortality attributed to hospital- acquire infections.

The present study showed that the majority of nurses and lab technicians had adequate level of knowledge about causative agent of AIDS, HBV and HCV. This finding goes in same line with study done in Canada by Rac et al. (1992) on registered nurses working in acute care setting indicated moderate scores for general knowledge about BBDs and high scores for modes of transmission and treatment. Also, Harkereader (2000) reported that preventing infection requires an understanding of how infectious diseases are transmitted or spread. Perry and Potter (2002) added that by understanding the chain of infection, the nurse can intervene to prevent infections from developing. On the other hand, this finding contradicts with study done in Tanta and Assiut by Shaaban and Baker (1990) and revealed that the nurses had low knowledge score about AIDS. Also, similar results of inadequate knowledge level regarding AIDS issues was found among maternity nurse and midwives (Hassan, 1992).
The current study illustrated that the minority of the nurses and lab technicians had inadequate level of knowledge about mode of transmission of BBDs from patient to nurses, and signs and symptoms of these diseases. Also, $20 \%$ of them had inadequate knowledge about sing and symptom of AIDS. This finding agree with study done in Saudi Arabia by Mandil et al. (2001) who estimated that most medical laboratory technicians had either poor or just satisfactory knowledge scores concerning HIV issues. Also the studies in the developed countries such as that carried among community nursing staff in Scotland reported that they had a limited knowledge about many aspects of HIV infection (Bond et al., 1990). Also, the study done in Canada on registered nurses working in acute care setting indicated a moderate score for general knowledge about BBDs (Rac et al., 1992).

The current study revealed that the majority of the studied subjects reported complete correct answer about complications of hepatitis B and C and $88.66 \%$ of them know causative agent of hepatitis B. This finding agrees with Chung (2005). On the other hand, the studied subjects reported inadequate knowledge about singe and symptom, and mode of transmission of hepatitis B and C. This finding goes in same line with study conducted in Washington by Kim et al. (1999), who reported inadequate knowledge about BBDs and also showed that the HCWs in their study were under used protective equipment during their work in emergency department.

As regard knowledge of the subjects about availability of equipments and supplies for universal precautions in the hospital, the study presented according to the nurses' answers that most of the equipments and supplies needed for universal precautions were present but inadequate amount except eye protections not present in the hospital. This finding is consistent with Ahmed (1997) and Abou Shady et al. (2001), who reported that the obstacles behind the application of universal precautions are the shortage of 
equipments and supplies. While contradicts with Taylor et al. (2001), who stressed that according to Occupational Safety and Health Act (OSHA) ruling, health care agencies must provide employees with equipments and supplies to minimize or prevent exposure to infectious material. In our view, decrease equipments and supplies needed for applications of universal precautions in the hospital lead to failure of nurses and lab technicians in application of the universal precautions.

Lastly, the interrelationships between the various study outcomes namely; knowledge and practice were investigated in the current study. Analysis of data showed that no statistically significant correlations between subjects' practice of infection control measures and their attendance of training courses. This is finding consistent with Ismail (2000), but it is inconsistent with Abdella (1999). Similarly, Attia (2001) explained that a highly significant difference was found between total nurses' knowledge scores and qualification in post test. Furthermore, Ahmed (1996) and Abdel All (1998) found that nurses with longer years of experience had better practice of universal precautions. Also, Sultan (2000) and Gohary (2001) found that there was an improvement in the level of performance with the increase in years of experience.

The present study reveled that there were positive correlation between nurses' practice and lab technicians' and available supplies in the hospital but the relations were not statistically significant, except the item of the ways of infection prevention, which has a significant statistical relation. This finding is consistent with Ahmed (1997) and Abou Shady et al. (2001), who reported that the obstacles behind the application of universal precautions are the shortage of equipments and supplies.

The current study showed that there were positive correlation between lab technicians' and nurses' practice and their attending training courses about infection control but the relation were not statistically significant. Also, between the studied subjects' total knowledge and their total practice. This finding goes in line with Zatton (2003), who mentioned that there was positive correlation between nurses' knowledge and performance while disagree with Chan (2002), who found no statistically significant correlation between lab technicians' and nurses' knowledge and compliance with universal precautions.

The study prove that the failure of nurses and lab technicians in application of universal precautions during their work due to lack of their knowledge and inadequate available amount of equipments and supplies need for applying universal precaution measures at hospital.

\section{Conclusion}

Majority of the studied sample have poor knowledge about sign and symptom and transmission of AIDS. Also, the majority of the studied sample has poor knowledge about sign and symptom and mode of transmissions of hepatitis B and C. In addition, all studied sample reported that there is no eye protection in the hospital. Positive correlation between lab technicians' and nurses' practice and available supplies in the hospital was found, but the relations were not statistically significant, except the item of the infection prevention ways has a significant statistical relation. Also, positive correlation between lab technicians' and nurses' practice and attending them for training courses about infection control were found, but the relations were not statistically significant.

\section{Recommendations}

Based on the main study findings, the following recommendation can be deduced:

1- Establishment of occupational health department which follows the rules regulation of OSHA such as evaluating personnel for existing infection, administering vaccines, keeping records, managing exposure and educating employee.

2- Infection control equipments and supplies should be available at hospitals.

3- Periodic and continuous education program for nurses and lab technicians about nosocomial infection, and universal precautions. 
4- A written policy and infection control manual should be available for all nurses and lab technicians at their work place.

5- Developing incentive and punishment system to nurses and lab technicians based on strict observation for their performance.

\section{References}

1. Abdel All S (1998): Factors affecting nurses' practice related to universal infection control precautions in haemodiaylsis unit of Tanta university hospital. Mater thesis, Faculty of Nursing, Alexandria University.

2. Abou Shady N, Ibrahim Y and Salem Y (2001): Implementation and education of educational program for nurses regarding nosocomial infection control at Mansoura university hospital. The Egyptian Journal of Medicine, 24 (5): 226-233.

3. Ahmed A (1996): Assessment of nurses' knowledge and practice regarding universal infection control precaution of blood borne pathogens. Master thesis, Faculty of Nursing, Alexandria University.

4. Ahmed A (1997): Assessment of health personnel knowledge, attitude and practice in relation to infection control in a general unit. Master thesis, High Institute of Nursing, Ain Shams University.

5. Abdella S (1999): Nosocomial infection control system in El Galaa Military Hospital. Mater thesis, High Institute of Nursing, Cairo University.

6. Attia FA (2001): A study of the effect of teaching program on prevention of nosocomial infection in peritoneal unit in Zagazig university hospital. MD Thesis, Faculty of Nursing, Zagazig University.

7. Bond S, Rhodes T, Philips $\mathbf{P}$ and Tierney A (1990): HIV infection and community nurse staff: Knowledge and attitudes. NT, 86(45): 49-51.

8. Castledine G and Close A (2007): Oxford handbook of general and adult nursing. New York: Oxford University Press, P. 600-614.

9. Chan R (2002): Nurses; knowledge and compliance with universal precautions in an acute hospital.Int J Nurs Stud,39(2):157-63.

10. Chung RT (2005): Acute hepatitis C virus infection. Clinical Diseases, 41 (suppl. 1): S14-S17.

11. Dewit S (2001): Fundamental concepts and skills for nursing. Philadelphia: WS Saunders Co, P. 228.
12. Duerink $\mathbf{D}$, Farida $\mathbf{H}$, Nagelkere $\mathbf{N}$, Wahyono H, Keuter M, Lastari E, Hadi $U$ and Von Den Broek $P$ (2006): Preventing nosocomial infections: improving compliance with stander precautions in an Indonesian teaching hospital. Journal of Hospital infection, 64: 36-43.

13. El Toukhy HM (1996): Staphylococcal infection in surgical department in Zagazig University Hospital: An epidemiological study. Doctorate Thesis, Faculty of Medicine, Zagazig University.

14. Faria S, Sodano L, Gjata A, Dauri M, Sabato AF, Biaj A, Mertiry O, Liazo E, Kodra Y and Schinaia N (2007): The first prevalence survey of nosocomial infections in the university hospital centre "Mother Teresa" of Tirana, Albania. Journal of Hospital Infection, 65: 244-250

15. Gohary AA (2001): Nurses' performance concerning infection control of patients with tuberculosis. Master Thesis, Faculty of Nursing, Ain Shams University.

16. Hassan N (1992): Attitude and practices of maternity nurses and midwives regarding prevention of HIV infection and AIDS. Thesis, MPH, Alexandria Faculty of Nursing, Alexandria University.

17. Harkereader H (2000): Fundamental of nursing care and clinical judgment. Philadelphia: WB Saunders Co Press, P. 602- 603.

18. Ismail $\mathbf{T}$ (2000): Assessment of nurses awareness, and attitude toward infection control concept at EL- Maniel university hospital. Master thesis, Faculty of Nursing, Cairo University.

19. Karmode M, Jolly D, Langkham B, Thomas MS, Holmes W and Gillord S (2005): Compliance with universal / standard precautions among health care workers in rural north India. AJIC, 33(1): 27-33.

20. Knight VM and Bods Worth NJ (1998): Perceptions and practices of universal blood and body fluid precautions by registered nurses at a major Sydney teaching hospital. J Adv Nurs, 27(4): 746-51.

21. Kim LE, Evanoff BA, Parks RL, Multha $S$ and Hasse C (1999): Compliance with universal precautions among emergency department personnel: Implication for prevention programs. Am J Infection Control, 27(5): 453-5.

22. Mandil AMA, Bashawri LA, Bahnassy AA and Al-Jamaa AA (2001): Knowledge, attitudes and practices for medical laboratory technologists towards HIV/AIDS, Eastern province, Saudi Arabia. Bulletin High Institute of Public Health, 31(1): 77-90. 
23. Parsons L and Krau S (2007): Bacterial infections: Management by acute and critical care nurses. Critical Care Nursing Clinics of North America, 19(1): 17-26.

24. Perry AG and Potter PA (2002): Clinical nursing skills techniques, $5^{\text {th }}$ Ed, St. Louis: Mosby co, P. 924-928.

25. Shaaban F and Bakr S (1990): Role expectations in AIDS control among HIN undergraduate and their clinical instructors. Bulleting High Institute of Public Health, 9: 829-39.

26. Storr J, Topley $K$ and Privett $S$ (2005): The ward nurse's role in infection control. Nursing Standard, 19 (41): 56-64.

27. Sultan T (2000): Assessment of nurses' awareness and attitude toward infection control concept at El Manial university hospital. Master thesis, Faculty of Nursing, Cairo University.

28. Rac D, Brown Y and Calder B (1992): Nurses knowledge and attitude toward patients with AIDS. Journal of Continuing Education in Nursing, 23(2): 69-75.

29. Rosdable CB (2000): Text book of basic nursing, $7^{\text {th }}$ Ed, New York: Lippincort Co, P. 428-445.

30. WHO (2004): Practical guidelines for infection control in health care facilities. www.Searo.Who.int/linkfiles/publications_ PrecticalguidelinSEAROpub41.pdf.

31. Taylor $\mathbf{C}$, Liillis $\mathbf{C}$ and Le Mone $\mathbf{P}$ (2001): Fundamentals of nursing the art and science of nursing care. $4^{\text {th }} \mathrm{Ed}$, New York: Lippincort Co, P. 534-562.

32. Talaat M, Kaneel A, Rasslan O, Hajjeh R, Hallaj Z, El-sayed $\mathbf{N}$ and Mahoney $\mathbf{F}$ (2006): Evolution of infection control in Egypt: Achievements and challenges. AJIC, 34(4): 194-200.

33. Zatton HK (2003): Assessment of knowledge and practice among nurses caring for patient with hepatitis. Master Thesis, Faculty of Nursing, Zagazig University. 


\section{الاستجابة للاحتياطات العامة}

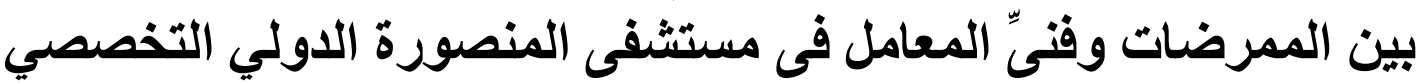

\section{سحر محمود سيد احمد ـ سلوى عباس على حسن - إيمان شكرى عبد اللة}

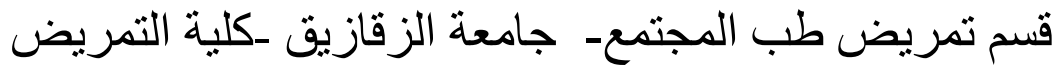

الأمر اض التي تنتقل عن طريق الدم مثل الإيدز و الالتهاب الكبدي الوبائي (بي) و

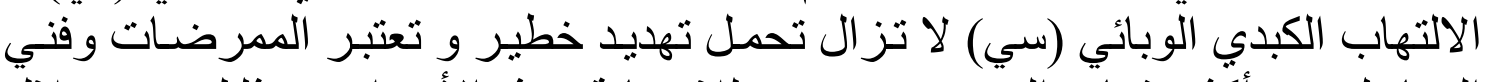

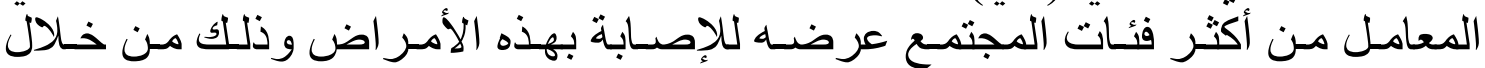

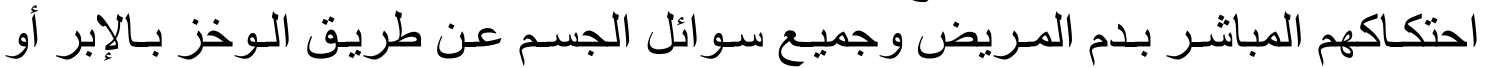

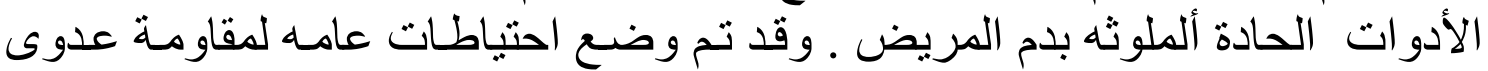

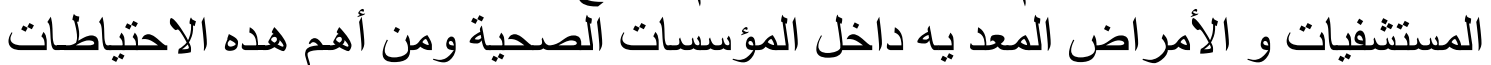

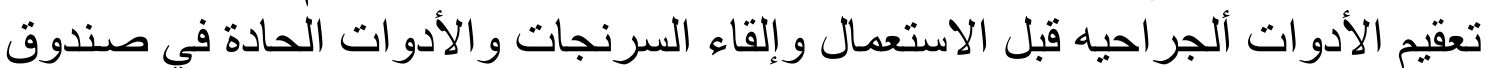

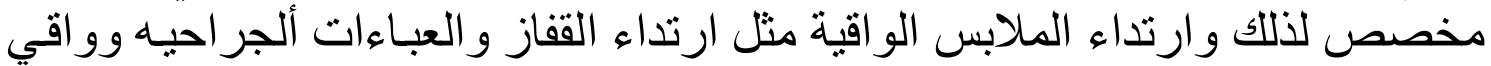

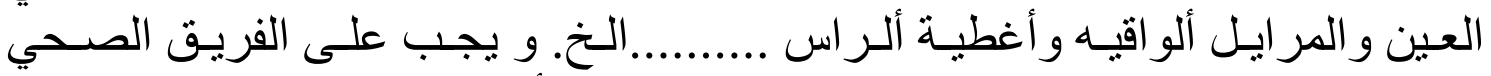

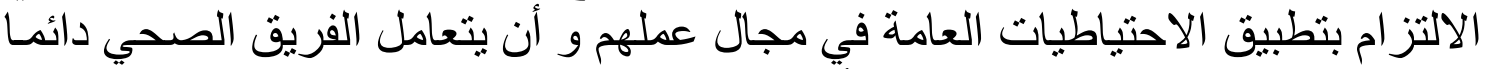

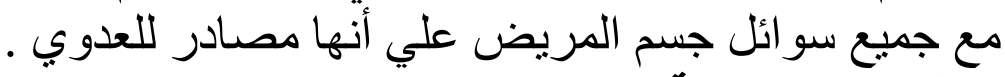

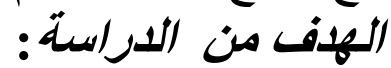

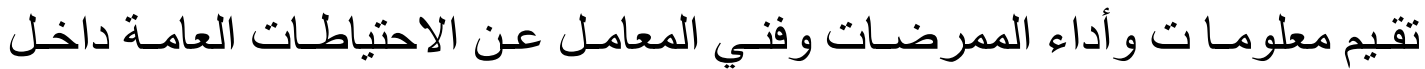

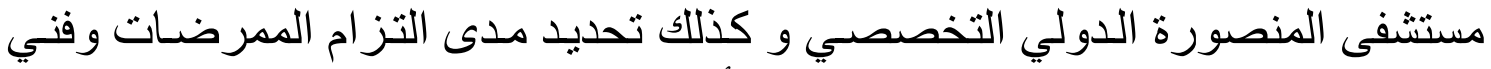

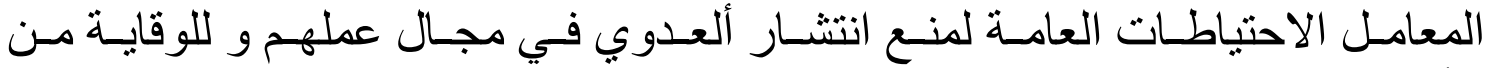

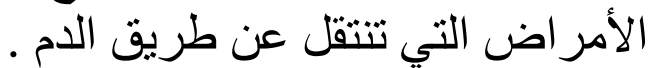

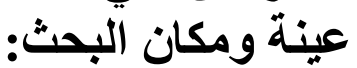

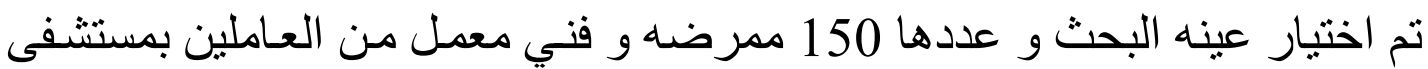

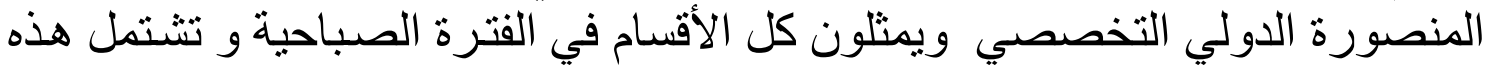

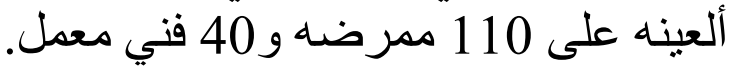
أدوات البعث: ألبنه

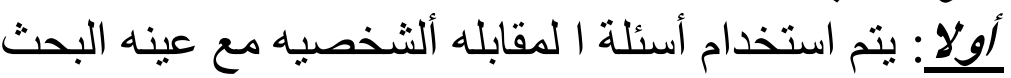

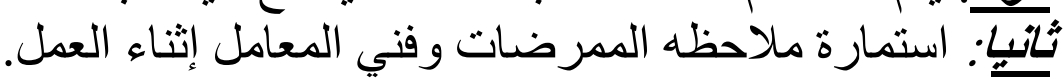

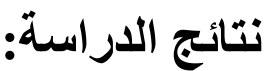

1 -قد أسفرت الدراسة اسة عن وجود قصور من جانب المستشفي في توفير بعض الأدوات

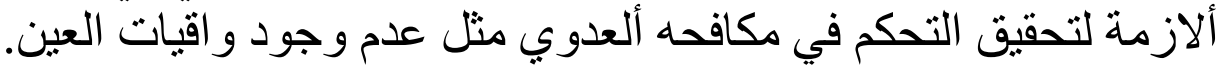




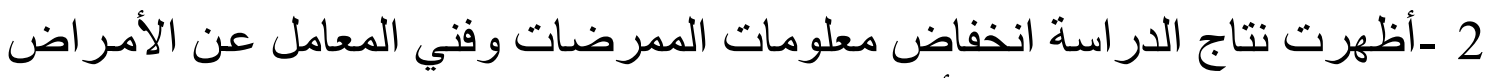

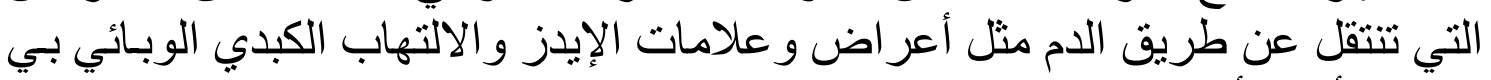

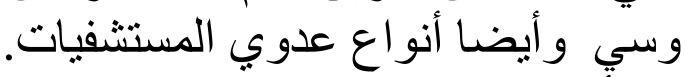
3 ـأُوضحت النتائج وجود اختوب التافات ذات دلالة إحصائية بين :

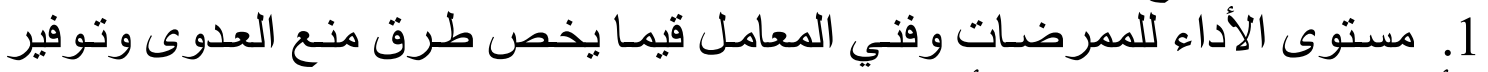
الأدوات اللازمة لمنع انتشار ألعدوي داخل المستشفي.

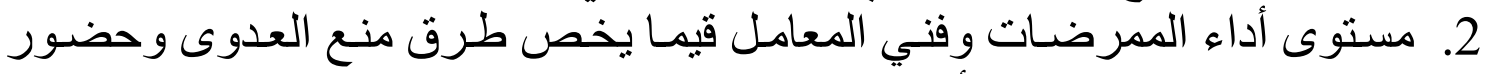

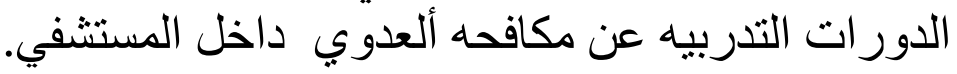

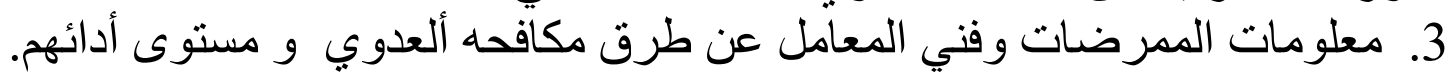
التوصيات و المقترحات: 1- إنشاء قسم لحماية أعضاء الفريق الصـاتهي بالمستشفى من الإخطار المهنية والتي تؤثر

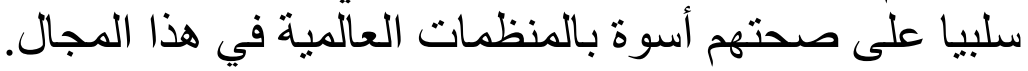

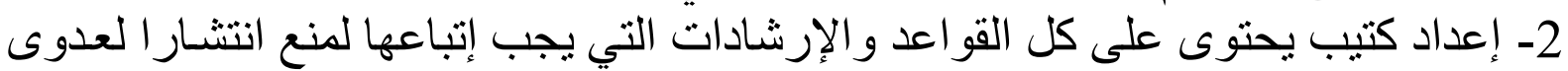

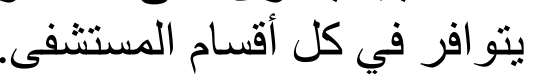

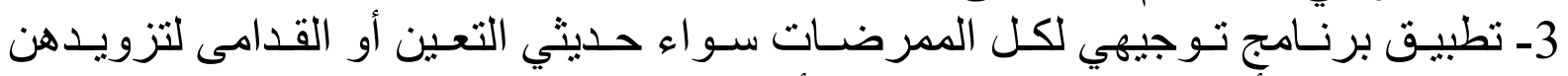

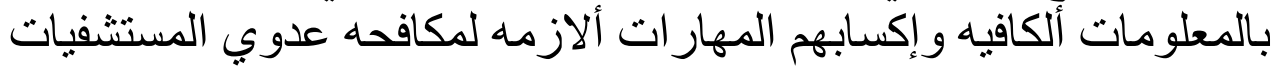

